\section{Tomato genotypes with determinate growth and high acylsugar content presenting resistance to spider mite}

\author{
Gabriel Mascarenhas Maciel ${ }^{1 *}$, Guilherme Repeza Marquez ${ }^{1}$, \\ Ernani Clarete da Silva ${ }^{2}$, Vanessa Andaló ${ }^{1}$ and Igor Forigo \\ Belloti $^{1}$
}

\begin{abstract}
Currently, the main control strategy for arthropod-pests in tomato cropping is the use of synthetic chemical insecticides and miticides. The study aimed to select tomato genotypes of Santa Cruz type, with determinate growth habit, which were rich in acylsugar and presented resistance to spider mite. The evaluated segregating populations were derived from interspecific crossing and were in the advanced generation $F_{2} B C_{2}$. Genotypes were assessed for acylsugars content, present in leaflets, trichomes at abaxial and adaxial parts and a repellence bioassay to the mite was performed. It was found that the genotype UFU-102- $F_{2} B C_{2} \# 13$ stood out in comparison to the others, showing determinate growth habit, high acylsugar content and resistance to spider mite. It was also possible to obtain genotypes that were similar to the wild specie $S$. pennellii, regarding the acylsugar content.
\end{abstract}

Key words: Allelochemical, biotic stress, growth habit, self-pruning gene, Tetranychus urticae.

\section{INTRODUCTION}

The tomato (Solanum lycopersicum L.) is the most widely cultivated vegetable crop worldwide. In 2012, over 69.000 hectares of tomato were cultivated in Brazil, where 24.000 hectares were occupied with cultivars that present determinate growth habit (industry and consumption in natura). More than 1.700 hectares were occupied with determinate cultivars, which were designed for in natura consumption, indicating significant participation in the setting of national tomato production combined with substantial growth in recent years (ABCSEM 2012).

Among the cultivated species, the tomato can be considered one of the most susceptible to arthropod pests (Resende et al. 2006, Pereira et al. 2008, Resende et al. 2008, Maciel et al. 2011, Oliveira et al. 2012, Czepak et al. 2013, Neiva et al. 2013, Maciel et al. 2014). Currently, the main recommendation for pest management is the chemical control (insecticides and miticides). That is the most used method since the 1970's (Sato et al. 2009, Silveira et al. 2011), which makes vital thinking about other strategies to reduce the exclusive use of it. Genetic improvement, aiming the resistance to arthropod pests, a type of biotic stress, and tomato diseases has been widely used in order to reduce such attacks (Maciel et al. 2009, Gonçalves Neto et al. 2010, Maluf et al. 2010, Oliveira et al. 2012, Neiva et al. 2013). In this sense, the use of the wild specie
Crop Breeding and Applied Biotechnology 18: 1-8, 2018 Brazilian Society of Plant Breeding. Printed in Brazil http://dx.doi.org/10.1590/198470332018v18n1a1

.


Solanum pennellii allows obtaining tomato lines (Maciel et al. 2009, Gonçalves Neto et al. 2010) and hybrids (Maluf et al. 2010, Maciel et al. 2011, Oliveira et al. 2012, Neiva et al. 2013) with broad-spectrum resistance to major arthropod pests, in tomato crop. This species presents an allelochemical named acylsugar, which when combined with the presence of glandular trichomes, becomes primarily responsible for conferring resistance to pests in tomato. The presence of acylsugar is due to an action of a recessive allele, with incomplete dominance towards low levels (Gonçalves et al. 2007).

Over the years, the demand for materials with determined growth habit has increased, since they have a better use of photoassimilates, do not require an extensive workforce and, because of that, their cultivation becomes cheaper (Maciel et al. 2016). Given the increased demand for determined growth plants, designed for in natura consumption, more research is needed, seeking to obtain genotypes rich in acylsugars, aiming to achieve a broad-spectrum resistance.

In tomato crops, the two-spotted spider mite, Tetranychus urticae Koch (Tetranychidae) is considered a main pest, that is capable of causing serious losses in the crops, by its extremely polyphagous and cosmopolitan behavior (Sato et al. 2009, Silveira et al. 2011). Losses of more than 30\% in the tomato crop were caused by this mite (Sato 2015).

Therefore, the objective of this study was to select tomato genotypes, obtained from crossing S. lycopersicum $\times S$. pennellii, that maintain the characteristic of determinate growth habit and show high acylsugars content, and therefore showing resistance to $T$. urticae.

\section{MATERIAL AND METHODS}

The genetic material used in the experiments was obtained from the Vegetable Germplasm Bank of the LAGEN (Laboratory of Genetic Resources). The segregating populations evaluated were obtained from the interspecific cross between the pre-commercial strain UFU-040 (S. lycopersicum) versus wild accession LA-716 (S. pennellii). UFU-040 is a pre-commercial line, with large fruits $(>180 \mathrm{~g})$, has low acylsugars content, is susceptible to pests, is a homozygous recessive genotype (spsp) for self-pruning, and has a genotypic background similar to the cultivar Santa Clara. The wild accession LA-716 has a high acylsugars content, small fruits (15 g), is resistant to pests (Maluf et al. 2010, Maciel et al. 2011) and has an indeterminate growth habit [dominant homozygote (SPSP) for self-pruning].

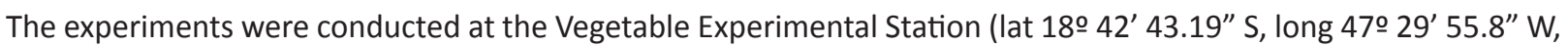
alt $873 \mathrm{~m}$ asl) and LAGEN of the Federal University of Uberlândia - UFU, Monte Carmelo Campus, in the period from May 2013 to April 2016. The study was conducted at different stages: obtaining and selecting $F_{2} B C_{1}$ plants rich in acylsugars; obtaining and selecting $\mathrm{F}_{2} \mathrm{BC}_{2}$ plants rich in acylsugars; leaf trichomes quantification and evaluation of the repellence to the two-spotted spider mite in $\mathrm{F}_{2} \mathrm{BC}_{2}$ plants.

For the selection of plants with high acylsugars content, $10 \mathrm{~F}_{2} \mathrm{BC}_{1}$ genotypes were used, which were, previously, obtained from self-fertilization of the first backcross $F_{1} B C_{1}$ : UFU-96- $F_{2} B C_{1} \# 4$, UFU-102- $F_{2} B C_{1} \# 8$, UFU-75- $F_{2} B C_{1} \# 4$, UFU-97- $F_{2} B C_{1} \# 1$, UFU-76- $F_{2} B C_{1} \# 2$, UFU-96- $F_{2} B C_{1} \# 2$, UFU-97- $F_{2} B C_{1} \# 2$, UFU-104- $F_{2} B C_{1} \# 7$, UFU-113- $F_{2} B C_{1} \# 2$, UFU-114- $F_{2} B C_{1} \# 2$ and the two check treatments, UFU-040 (low acylsugar content) and LA-716 wild accession (S. pennellii) (high acylsugar content).

The genotypes were sowed in polystyrene trays with 200 cells, filled with substrate of coconut fiber. Thirty-five days after sowing, the seedlings were transplanted to $500 \mathrm{~mL}$ pots, containing the same substrate that was used for the seedlings production. The tomato plants were grown in a greenhouse of type arch, with dimensions of $7 \times 21 \mathrm{~m}$ and ceiling $4 \mathrm{~m}$, covered with transparent polyethylene film of 150 microns, additivated against ultraviolet rays and with curtain side of anti-aphid white screen.

The experiment was conducted in a randomized block design, containing two replications, totalizing 24 plots (12 genotypes $x 2$ blocks). Each plot was represented by 10 plants. Eighty-five days after sowing, the leaflets were collected in order to quantify the acylsugars content. For the allelochemical extraction, six leaf discs (equivalent to $4.2 \mathrm{~cm}^{2}$ ), from all plants, were collected. The discs were collected from leaflets present in the upper third of the plants. After being collected, they were placed on test tubes and the chemical analysis was conducted, according to the methodology proposed by Resende et al. (2002). Among the 200 plants obtained, from the 10 evaluated populations, those that presented acylsugar levels similar to the parent donor (wild accession LA-716) were selected. From these previously selected plants, the second backcross was again performed using the recurrent parent (UFU-040). In possession of $F_{1} B C_{2}$ seeds, a new sowing was done and during the reproductive phase of the plants, by natural self-fecundation, advanced 
Tomato genotypes with determinate growth and high acylsugar content presenting resistance to spider mite

genotypes $\mathrm{F}_{2} \mathrm{BC}_{2}$ were obtained.

After obtaining $\mathrm{F}_{2} B C_{2}$ genotypes, a sowing with them (second backcross), the genitor recurrent (UFU-040, low acylsugar content), the parent donor (wild accession LA-716, rich in acylsugar) and the commercial cultivar Santa Clara, was made. All genotypes were sown in a polystyrene trays of 200 cells, filled with commercial substrate of coconut fiber. Thirty-two days after sowing, the seedlings were transplanted into $500 \mathrm{~mL}$ pots. The experiment was conducted in a greenhouse type arch, with dimensions of $7 \times 21 \mathrm{~m}$ and ceiling $4 \mathrm{~m}$, covered with transparent polyethylene film of 150 microns, additivated against ultraviolet rays and with curtain side of anti-aphid white screen.

The experiment was conducted in a randomized block design, containing two replications and nine treatments (genotypes), culminating in 18 plots. Eighty-five days after sowing, the leaflets were collected, in order to quantify the acylsugars content, according to the methodology proposed by Resende et al. (2002).

In order to quantify the glandular trichome (types I, IV, VI and VII), the same plants used in the previous experiment were used, making it possible to compare the results. Fifty days after transplanting the plants into pots, young and expanded leaflets were collected from the upper third of each plant. Aiming to quantify the epidermal glandular trichomes, present in the faces (abaxial and adaxial) of the leaflets, a stereoscopic microscope (40X) with a micrometer scale of 1 $\mathrm{cm}^{2}$ was used. Five leaves per plant in each population were evaluated, totalizing 50 samples per plot.

The two-spotted spider mite, T. urticae, that were used in the experiment, were collected in commercial fields, on S. Iycopersicum tomato leaves, in Monte Carmelo city (Minas Gerais state), in January 2016, and reared. The structure used for rearing the mites was consisted of a greenhouse type arch $(6 \times 4 \mathrm{~m})$, ceiling $2 \mathrm{~m}$, covered with transparent polyethylene film of 150 microns, additivated against ultraviolet rays and with curtain side of anti-aphid white screen.

The resistance to the mite was quantified according to a repellency test, proposed by Weston and Snyder (1990), measuring the distances covered by the mites on the surface of the leaflets. Tests were performed at 5, 10, 15 and 20 minutes, started after five mites were placed on a thumbtack, that was fixed in the center of each leaflet.

The results were submitted to a variance analysis ( $F$ test $p<0.05)$ and, in case of a significant effect, the Tukey test was performed $(p<0.05)$, in order to compare the means for acylsugars content and trichomes density, and regression analysis to evaluate the repellency to the mite. The analyses were performed with the assistance of the software Genes (Cruz 2013). Contrasts of interest were performed, applying the Scheffé test $p<0.05$ and 0.01 ), in order to compare the check treatments versus groups of the best genotypes, using the statistical analysis software Sisvar 5.3 (Ferreira 2000).

\section{RESULTS AND DISCUSSION}

According the selection of $\mathrm{F}_{2} \mathrm{BC}$ genotypes, there were significant differences between the materials, referring to acylsugars content, compared to the recurrent parent (Table 1). Wild accession S. pennellii (LA-716) differed, significantly, from the UFU-040, showing $89.24 \%$ of relative superiority in relation to the pre-commercial strain. This result agrees with the data obtained in several studies (Maciel et al. 2009, Gonçalves Neto et al. 2010, Maluf et al. 2010, Maciel et al. 2011, Oliveira et al. 2012, Neiva et al. 2013, Maciel et al. 2014), indicating the potential of the wild accession, S. pennellii, due to its high acylsugars content in the leaflets, when compared to commercial or pre-commercial cultivars.

Among the genotypes, some of them stood out for the presence of acylsugars: UFU-96- $F_{2} B C_{1} \# 4, U F U-102-F_{2} B C_{1} \# 8$, UFU-97- $F_{2} B C_{1} \# 1$, UFU-97- $F_{2} B C_{1} \# 2$, UFU-104- $F_{2} B C_{1} \# 7$ and UFU-114- $F_{2} B C_{1} \# 2$, since these did not differ, significantly, from the wild accession LA-716 (Table 1). There are strong indications that acylsugars is predominantly responsible for giving a broad spectrum-resistance to pests in tomato (Maluf et al. 2010, Maciel et al. 2011). However, several authors (Resende et al. 2006, Gonçalves et al. 2007, Maluf et al. 2010, Maciel et al. 2011, Oliveira et al. 2012, Neiva et al. 2013) have reported not only the presence of acylsugars, but also other factors could be associated with the resistance conferred by the wild accession S. pennellii, preventing the possibility to obtain genotypes with the same resistance range. This finding was also observed in the present study, for the $F_{2} B C_{1}$ generation, when the contrasts $C 2$ and $C 4$ (Table 1 ) were evaluated. According to the contrast $\mathrm{C} 1$, it is possible to verify that all $\mathrm{F}_{2} \mathrm{BC}$ genotypes obtained were superior to the recurrent parent (UFU-040). When evaluated in the same group (C3), the best genotypes were UFU-96- $F_{2} B C_{1} \# 4, U F U-102-F_{2} B_{1} \# 8$ and UFU-97- $F_{2} B C_{1} \# 1$, differing significantly from the pre-commercial control (UFU-040). Moreover, observing the relative superiority of the same genotypes, UFU-96-F2BC1\#4 UFU-102-F2BC1\#8 and UFU-97- $\mathrm{F}_{2} B C_{1} \# 1$, higher values were found 
Table 1. Levels of acylsugar ( $\mathrm{nmols} \mathrm{cm}^{-2}$ of leaf area) in tomato genotypes at $\mathrm{F}_{2} \mathrm{BC}_{1}$ generation and in the related genitor Solanum pennellii, LA-716 accession (donor parent) and Solanum lycopersicum, UFU-040 accession (recurrent parent)

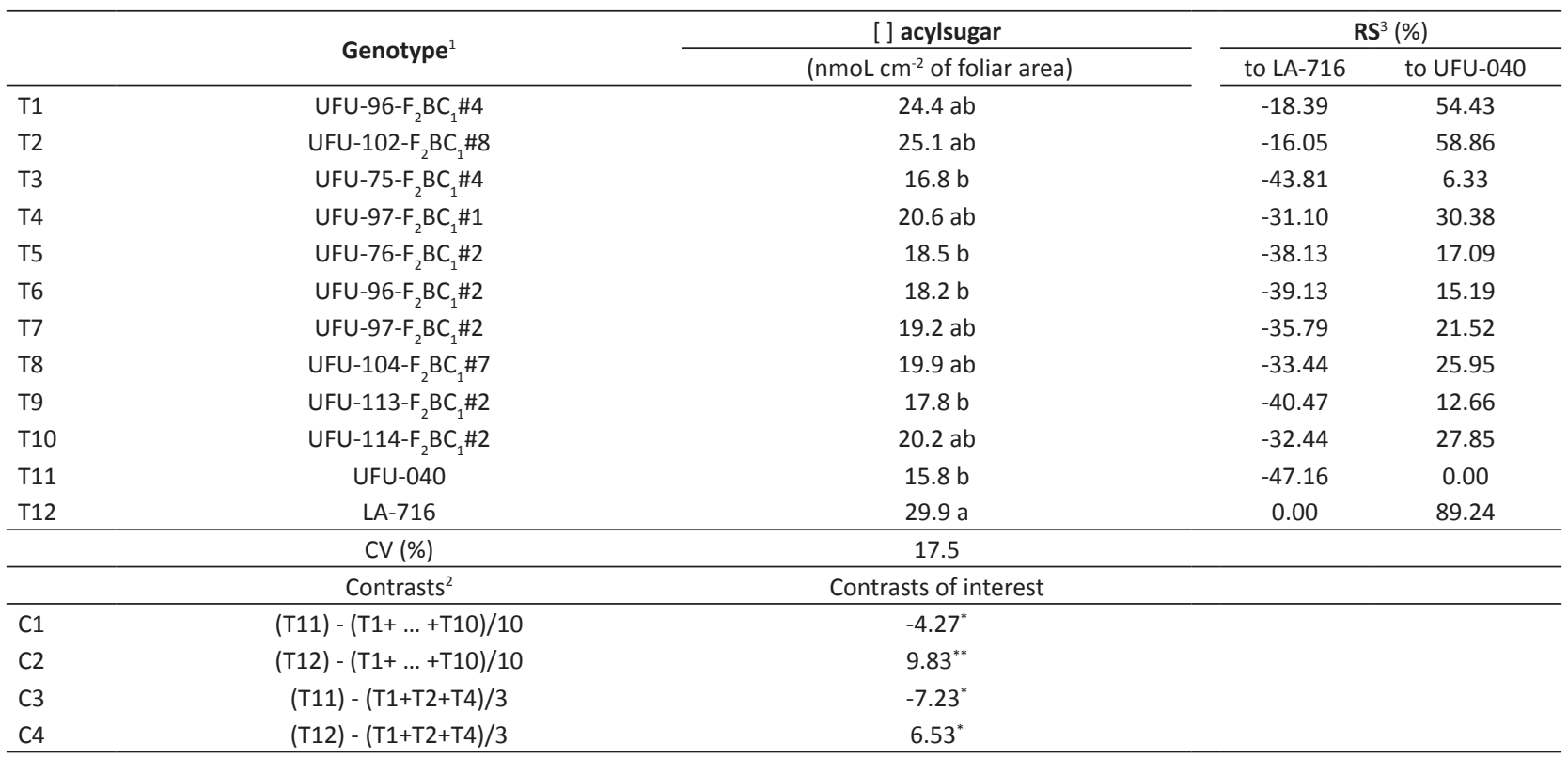

${ }^{1}$ Means followed by the same letter in the column did not differ significantly from each other, Tukey, $p<0.05 ;^{2 * *}{ }^{*}=$ significant $\alpha=0.01$ and $\alpha=0.05$ respectively, by the Scheffé test; ${ }^{3}$ Relative superiority.

for acylsugars content when they were compared with the recurrent parent $(54.43 ; 58.86$ and $30.38 \%$, respectively) (Table 1). Such superiority was used as an indicator to select the best genotypes and performed the second backcross $\left(F_{1} B C_{2}\right)$, and after that, to performed the self-cross to obtain the advanced generations $\left(F_{2} B C_{2}\right)$ (Table 2$)$.

After obtaining the advanced $\mathrm{F}_{2} \mathrm{BC}_{2}$ genotypes (Table 2), the acylsugars content was evaluated and compared with the check treatments (Table 3). Significant differences between genotypes (Tukey, 5\% probability) were verified for acylsugars content.

Regarding the glandular trichome scores, in the abaxial and adaxial faces, it was observed that were differences among the evaluated genotypes. The wild accession S. pennellii had 81.9 and $73.1 \mathrm{~cm}^{-2}$ more trichomes, compared to the cultivar Santa Clara and to the pre-commercial strain UFU-040 on the abaxial face, respectively, differing significantly from them (Tukey $5 \%$ probability). The same was observed when assessing the adaxial part of the leaflet. S. pennellii demonstrated superiority of 74 and 75.5 trichomes $\mathrm{cm}^{-2}$, compared to the cultivar Santa Clara to the pre-commercial strain UFU-040 (Table 3). These results agree with other studies that report the low presence of glandular trichomes on cultivated tomatoes (Glas et al. 2012) and the outstanding presence in wild species (Lucatti et al. 2013).

There is evidence that the trichomes on commercial tomato cultivars are higher found at the initial stage of the plant development, and a reduction comes as the phenological stages advance (Li 2004). This fact could explain the difficulty or lack of efficiency in selecting plants, indirectly, aiming resistance to pests based only on the trichomes density in the leaflets.

Related to acylsugars content, the genotype UFU-102- $\mathrm{F}_{2} \mathrm{BC}_{2} \# 13$ highlighted and did not differ, significantly, from the wild accession S. pennellii (Tukey $5 \%$ probability). Comparing with cultivar Santa Clara, UFU-102- $\mathrm{F}_{2} \mathrm{BC}_{2} \# 13$ presents relative superiority of $65.11 \%$ in relation to acylsugars content (Table 3 ). The value obtained in the contrast C3 (11.59 $\mathrm{nmoL}$ of acylsugar $\mathrm{cm}^{-2}$ of leaf area) indicates the superiority of the genotype UFU-102- $\mathrm{F}_{2} \mathrm{BC}_{2} \# 13$ compared to the recurrent parent (UFU-040) and compared to the cultivar Santa Clara, allowing us to state that there is a superiority to the commercial cultivars. Similar results were obtained by several authors (Gonçalves Neto et al. 2010, Maluf et al. 2010, Maciel et al. 2011) when evaluating tomato genotypes after successive backcrosses. However, only the genotypes that bear indeterminate growth habit were emphasized. 
As mentioned before, there are no advanced tomato genotypes, rich in acylsugars, with determinate growth habit and designed for in natura consumption. Thus, UFU-102- $\mathrm{F}_{2} \mathrm{BC}_{2} \# 13$ can be considered an excellent genotype, since it is rich in acylsugars, and it is also promising in order to encourage future breeding programs. In contrast, the other genotypes, UFU-96- $\mathrm{F}_{2} B C_{2} \# 2$, UFU-96- $\mathrm{F}_{2} \mathrm{BC}_{2} \# 7$, UFU-97- $\mathrm{F}_{2} B \mathrm{C}_{2} \# 4$, UFU-102- $\mathrm{F}_{2} B C_{2} \# 8$, UFU-102- $\mathrm{F}_{2} B \mathrm{C}_{2} \# 15$ and UFU-102$\mathrm{F}_{2} \mathrm{BC}_{2} \# 13$ had low acylsugars content and they were not recommended for forward generations or to get homozygous lineage. However, it is noteworthy that there is a possibility that tomato hybrids with intermediate levels of acylsugar present a broad-spectrum resistance to pests (Maluf et al. 2010).

In tomato genotypes of indeterminate growth, several studies have demonstrated the absence of transgressive segregation and, even the inferiority in acylsugars content of the genotypes selected for high levels, in relation to the wild accession S. pennellii (Gonçalves et al. 2007, Pereira et al. 2008, Resende et al. 2008, Maciel et al. 2009, Gonçalves

Table 2. Description of pre-selected genotypes at $\mathrm{F}_{2} \mathrm{BC}_{1}$ generation, Solanum pennellii, LA-716 accession (donor parent), Solanum lycopersicum, UFU-040 accession (recurrent parent) and commercial cultivar Santa Clara

\begin{tabular}{|c|c|}
\hline Genotypes/Treatments & Description \\
\hline UFU-96- $\mathrm{F}_{2} \mathrm{BC}_{2} \# 2$ & $\begin{array}{l}\text { Genotype selected } \mathrm{F}_{2} \mathrm{BC}^{2} \text {, from the interspecific cross between Solanum pennellii versus Solanum } \\
\text { lycopersicum (UFU-040). (homozygous recessive (spsp) for self-pruning). }\end{array}$ \\
\hline UFU-96- $\mathrm{F}_{2} \mathrm{BC}_{2} \# 7$ & $\begin{array}{l}\text { Genotype selected } \mathrm{F}_{2} \mathrm{BC}_{2} \text {, from the interspecific cross between Solanum pennellii versus Solanum } \\
\text { lycopersicum (UFU-040). (homozygous recessive (spsp) for self-pruning). }\end{array}$ \\
\hline UFU-97- $\mathrm{F}_{2} \mathrm{BC}_{2} \# 4$ & $\begin{array}{l}\text { Genotype selected } \mathrm{F}_{2} \mathrm{BC}_{2} \text {, from the interspecific cross between Solanum pennellii versus Solanum } \\
\text { lycopersicum (UFU-040). (homozygous recessive (spsp) for self-pruning). }\end{array}$ \\
\hline UFU-040 & $\begin{array}{l}\text { Pre-commercial lineage with low acylsugar content (A.A). (homozygous recessive (spsp) for self- } \\
\text { pruning) genotypic background similar to Santa Clara cultivar. }\end{array}$ \\
\hline UFU-102- $\mathrm{F}_{2} \mathrm{BC}_{2} \# 8$ & $\begin{array}{l}\text { Genotype selected } \mathrm{F}_{2} \mathrm{BC}_{2} \text {, from the interspecific cross between Solanum pennellii versus Solanum } \\
\text { lycopersicum (UFU-040). (homozygous recessive ( } s p s p \text { ) for self-pruning). }\end{array}$ \\
\hline UFU-102- $\mathrm{F}_{2} \mathrm{BC}_{2} \# 15$ & $\begin{array}{l}\text { Genotype selected } \mathrm{F}_{2} \mathrm{BC}_{2} \text {, from the interspecific cross between Solanum pennellii versus Solanum } \\
\text { lycopersicum (UFU-040). (homozygous recessive (spsp) for self-pruning). }\end{array}$ \\
\hline UFU-102- $\mathrm{F}_{2} \mathrm{BC}_{2} \# 13$ & $\begin{array}{l}\text { Genotype selected } \mathrm{F}_{2} \mathrm{BC}_{2^{\prime}} \text { from the interspecific cross between Solanum pennellii versus Solanum } \\
\text { lycopersicum (UFU-040). (homozygous recessive (spsp) for self-pruning). }\end{array}$ \\
\hline
\end{tabular}

Table 3. Levels of acylsugar (nmols $\mathrm{cm}^{-2}$ of leaf area) in tomato genotypes in $\mathrm{F}_{2} \mathrm{BC}_{2}$ generation and the genitor Solanum pennellii, LA-716 accession (donor parent) and Solanum lycopersicum, UFU-040 accession (recurrent parent)

\begin{tabular}{|c|c|c|c|c|c|c|}
\hline & \multirow[b]{2}{*}{ Genotype $^{1}$} & \multicolumn{2}{|c|}{$\begin{array}{c}\text { Glandular trichome type I, IV, VI and VII } \mathrm{cm}^{-2} \\
\text { (Glas et al. 2012) }\end{array}$} & \multirow{2}{*}{$\begin{array}{c}\text { [ ] acylsugars } \\
\text { (Resende et al. 2002) } \\
\begin{array}{c}\text { (nmoL cm }{ }^{-2} \text { of foliar } \\
\text { area) }\end{array}\end{array}$} & \multicolumn{2}{|c|}{$\begin{array}{l}\mathbf{R S}^{3} \text { in relation to } \\
\text { acylsugar content }(\%)\end{array}$} \\
\hline & & Abaxial & Adaxial & & LA-716 & UFU-040 \\
\hline $\mathrm{T} 2$ & UFU-96- $\mathrm{F}_{2} \mathrm{BC}_{2} \# 7$ & $3.4 b c$ & $1.4 \mathrm{~cd}$ & $19.37 b$ & -36.39 & 11.51 \\
\hline T3 & UFU-97- $\mathrm{F}_{2} \mathrm{BC}_{2} \# 4$ & $1.6 \mathrm{c}$ & $4.7 b$ & $16.38 b$ & -46.21 & -5.70 \\
\hline T4 & UFU-040 & $1.9 c$ & $0.9 d$ & $17.37 \mathrm{~b}$ & -42.96 & 0.00 \\
\hline T6 & UFU-102- $\mathrm{F}_{2} \mathrm{BC}_{2} \# 15$ & $6.8 b$ & $4.3 b$ & $18.30 \mathrm{~b}$ & -39.90 & 5.35 \\
\hline $\mathrm{T7}$ & UFU-102- $F_{2} B_{2} \# 13$ & $5.4 b c$ & $3.9 b c$ & $28.68 a$ & -5.81 & 65.11 \\
\hline T8 & cv. Santa Clara & $2.1 \mathrm{c}$ & $2.4 c d$ & $12.81 \mathrm{~b}$ & -57.93 & -26.25 \\
\hline \multirow[t]{2}{*}{ T9 } & Solanum pennellii & $84.0 \mathrm{a}$ & $76.4 a$ & $30.45 a$ & 0.00 & 75.30 \\
\hline & CV (\%) & 9.13 & 5.94 & 8.48 & & \\
\hline C3 & (T7) - (T4+T8)/2 & 1.4 & 2.2 & $11.59^{*}$ & & \\
\hline
\end{tabular}

${ }^{1}$ Means followed by the same letter in the column did not differ significantly from each other, Tukey, $p<0.05 ;{ }^{2 * *},{ }^{*}$ significant $\alpha=0.01, \alpha=0.05$, respectively, by the Scheffé test; ${ }^{3}$ Relative superiority. 

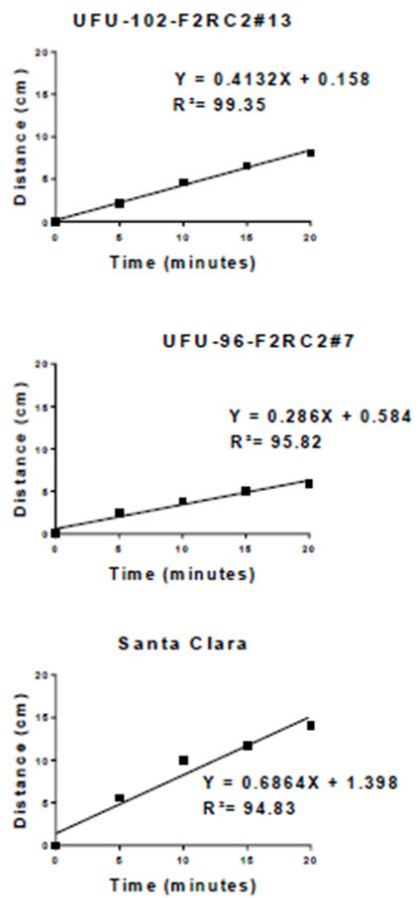

UFU - 96-F 2RC 2 \#2

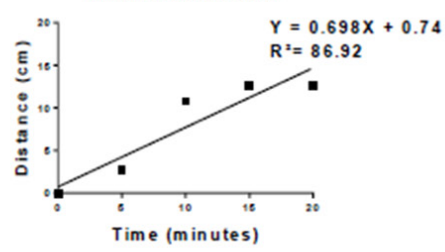

UFU -102-F2RC2\#15

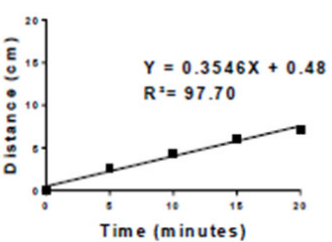

Solanum pennellii

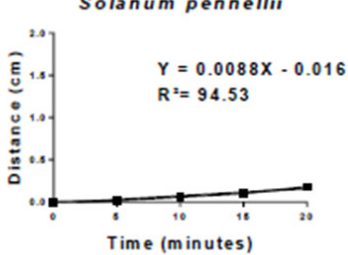

UFU -97-F2RC2\#4

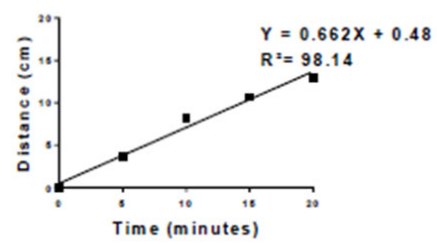

UFU -102-F 2R C 2 \# 8

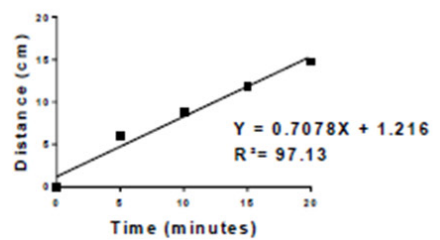

UFU -040

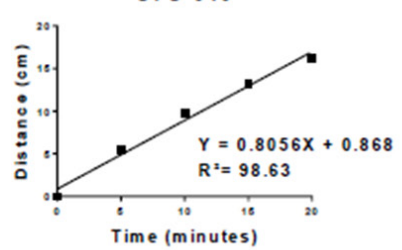

Figure 1. Regression equations for the average distance covered by Tetranychus urticae in function of the time $(5,10,15$ and 20 minutes) at different tomato genotypes.

Neto et al. 2010, Maciel et al. 2011, Oliveira et al. 2012, Neiva et al. 2013, Maciel et al. 2014). In the present study, the superiority of the wild accession, $S$. pennellii, was verified when compared with $\mathrm{F}_{2} \mathrm{BC}_{2}$ genotypes, but the genotype UFU-102- $\mathrm{F}_{2} \mathrm{BC}_{2} \# 13$ was similar to the wild accession, not differing, significantly, from it (Tukey test, $5 \%$ probability). This similarity suggests the possibility of getting tomato genotypes, with determinate growth, and with acylsugar levels close to wild accession S. pennellii.

It was found, in the previously selected genotypes, that independent of them, the mites walked on the surface of the leaflets (Figure 1). Generally, the mite displacement was reduced or stalled when genotypes with higher acylsugar content were evaluated. In the wild accession (S. pennellii), there were pronounced restrictions of mites displacements on the surface of the leaflets. These factors could be associated with the presence of trichomes and/or in function of the increased presence of acylsugars.

It is notable that the genotype UFU-102- $\mathrm{F}_{2} \mathrm{BC}_{2} \# 13$, previously identified as rich in acylsugars $(65.11 \%$ higher than the UFU-040, recurrent parent) also caused reduced displacement of the mite (Figure 1); so, the genotype UFU-102$\mathrm{F}_{2} \mathrm{BC}_{2} \# 13$, can be considered to have a potential resistance to the mite. In contrast, the greatest distances roamed by the mites were found in both commercial cultivar and recurrent parent (Figure 1). These results agree with the works developed by Resende et al. (2008), where it was found that commercial cultivars presented higher displacement of mites, and by Silva et al. (2009), that obtained restrictions of mite displacement on the surface of the leaflets of $S$. pennellii and in the genotypes rich in acylsugar.

\section{CONCLUSION}

It was possible to select tomato genotypes of Santa Cruz type, with determinate growth habit, desirable levels of acylsugars and satisfactory resistance levels to T. urticae. 
Tomato genotypes with determinate growth and high acylsugar content presenting resistance to spider mite

In tomato with determinate growth habit, in the generation $\mathrm{F}_{2} \mathrm{BC}_{2}$, it was possible to obtain a genotype similar to the wild accession, S. pennellii, related to acylsugar content.

\section{ACKNOWLEDGEMENTS}

The authors thank FAPEMIG, CNPq and UFU, for financial support, fellowships and provision of infrastructure.

\section{REFERENCES}

ABCSEM - Associação Brasileira de Comércio de Sementes e Mudas (2012) Dados do setor de pesquisa de mercado de sementes de hortaliças. Available at <www.abcsem.com.br/dadosdosegmento. php>. Accessed on May 3, 2016.

Cruz CD (2013) GENES: A software package for analysis in experimental statistics and quantitative genetics. Acta Scientiarum. Agronomy 35: 271-276.

Czepak C, Albernaz KC, Vivian LM, Guimarães HO and Carvalhais T (2013) Primeiro registro de ocorrência de Helicoverpa armigera (Hübner) (Lepidoptera: Noctuidae) no Brasil. Pesquisa Agropecuária Tropical 43: 110-113.

Ferreira DF (2000) Análises estatísticas por meio do Sisvar para Windows versão 4.0. In Anais da reunião anual da região brasileira da sociedade internacional de biometria 45. SIB, São Carlos, p. 255-258.

Glas JJ, Schimmel BC, Alba JM, Escobar-bravo R, Schuurink RC and Kant MR (2012) Plant glandular trichomes as targets for breeding or engineering of resistance to herbivores. International Journal of Molecular Sciences 13: 17077-17103.

Gonçalves LD, Maluf WR, Cardoso MG, Gomes LAA and Nascimento IR (2007) Herança de acilaçúcares em genótipos de tomateiro provenientes de cruzamento interespecífico. Pesquisa Agropecuária Brasileira 42: 699-705.

Gonçalves Neto AC, Silva VF, Maluf WR, Maciel GM, Nizio DAC, Gomes LAA and Azevedo SM (2010) Resistência à traça-do-tomateiro em plantas com altos teores de acilaçúcares nas folhas. Horticultura Brasileira 28: 203-208.

Li L, Zhao Y, McCaig BC, Wingerd BA, Wang J, Whalon ME, Pichersky E and Howe GA (2004) The tomato homolog of coronative-insensitive1 is required for the maternal control of seed maturation, jasmonatesignaled defense responses, and glandular trichome development. The Plant Cell 16: 126-143.

Lucatti AF, van Heusden AW, de Vos RC, Visser RGF and Vosma B (2013) Differences in insect resistance between tomato species endemic to the Galapagos Islands. BMC Evolutionary Biology 13:175.

Maciel GM, Maluf WR, Silva VF, Gonçalves Neto AC, Hayata L, Carvalho RC, Moretto P, Licursi V and Moretto DP (2009) Heterose e capacidade combinatória em linhagens de tomateiro na obtenção de híbridos com teores intermediários de acilaçúcares. Horticultura Brasileira 27: 1161-1167.

Maciel GM, Maluf WR, Silva VF, Gonçalves Neto AC and Gomes LAA (2011) Híbridos pré-comerciais resistentes a Tuta absoluta obtidos de linhagem de tomateiro rica em acilaçúcares. Horticultura Brasileira 29: 151-156.

Maciel GM and Silva EC (2014) Proposta metodológica para quantificação de acilaçúcares em folíolos de tomateiro. Horticultura Brasileira 32: 174-177.

Maciel GM, Fernandes MAR, Melo OD and Oliveira CS (2016) Potencial agronômico de híbridos de minitomate com hábito de crescimento determinado e indeterminado. Horticultura Brasileira 34: 144-148.

Maluf WR, Maciel GM, Gomes LAA, Cardoso MG, Gonçalves LD, Silva EC and Knapp M (2010) Broad-spectrum arthropod resistance in hybrids between high and low-acylsugar tomato lines. Crop Science 50: 439-450.

Neiva IP, Andrade Júnior VC, Maluf WR, Oliveira CM and Maciel GM (2013) Role of allelochemicals and trichome density in the resistance of tomato to whitefly. Ciência e Agrotecnologia 37: 61-67.

Oliveira CM, Andrade Júnior VC, Maluf WR, Neiva IP and Maciel GM (2012) Resistance of tomato strains to the moth Tuta absoluta imparted by allelochemicals and trichome density. Ciência e Agrotecnologia 36: 45-52.

Pereira GVN, Maluf WR, Gonçalves LD, Nascimento IR, Gomes LAA and Licursi V (2008) Seleção para alto teor de acilaçúcares em genótipos de tomateiro e sua relação com a resistência ao ácaro vermelho (Tetranychus evansi) e à traça (Tuta absoluta). Ciência e Agrotecnologia 32: 996-1004.

Resende JTV, Cardoso MG, Maluf WR, Santos CD, Gonçalves LD, Resende LV and Naves FO (2002) Método colorimétrico para quantificação de acilaçúcar em genótipos de tomateiro. Ciência e Agrotecnologia 26: 1204-1208.

Resende JTV, Maluf WR, Faria MV, Pfann AZ and Nascimento IR (2006) Acylsugars in tomato leaflets confer resistance to the south american tomato pinworm, Tuta absoluta Meyr. Scientia Agricola 63: 20-25.

Resende JTV, Maluf WR, Cardoso MG, Faria MV, Gonçalves LD and Nascimento IR (2008) Resistance of tomato genotypes with high level of acylsugars to Tetranychus evansi. Scientia Agricola 65: 31-35.

Sato ME, Silva MZ, Silva RB, Souza Filho MF and Raga A (2009) Monitoramento da resistência de Tetranychus urticae Koch (Acari: Tetranychidae) a Abamectin e Fenpyroximate em diversas culturas no estado de São Paulo. Arquivos do Instituto Biológico 76: 217-223.

Sato ME (2015) Ácaro rajado em tomate tem assustado produtores. Revista campos \& negócios. Available at <http://www. revistacampoenegocios.com.br/acaro-rajado-em-tomate-temassustado-produtores>. Accessed on May 4, 2016. 
Silva VF, Maluf WR, Cardoso MG, Gonçalves Neto AC, Maciel GM, Nízio DAC and Silva VAS (2009) Resistência mediada por aleloquímicos de genótipos de tomateiro à mosca-branca e ao ácaro-rajado. Pesquisa Agropecuária Brasileira 44: 1262-1269.

Silveira LFV, Polanczyk D and Pratissoli CR (2011) Franco Seleção de isolados de Bacillus thuringiensis Berliner para Tetranychus urticae Koch. Arquivos do Instituto Biológico 78: 273-278.

Weston PA and Snyder JC (1990) Thumbtack biossay: a quick method of measuring plant resistence to twospotted spider mites (Acari: Tetranychidae). Journal of Economic Entomology 83: 501-504. 